\title{
Overcoming ICT Barriers in IBS Management Process in Malaysia Construction Industry
}

\author{
Peniel Ang Soon Ern ${ }^{1, *}$, Narimah Kasim ${ }^{2}$, Md Asrul Nasid Masrom ${ }^{2}$, and Goh Kai Chen ${ }^{2}$ \\ ${ }^{1}$ Department of Civil Engineering Technology, Faculty of Engineering Technology, Universiti Tun \\ Hussein Onn Malaysia, 86400 Parit Raja, Johor, Malaysia \\ ${ }^{2}$ Department of Construction Management, Faculty of Technology Management and Business, \\ Universiti Tun Hussein Onn Malaysia, 86400 Parit Raja, Johor, Malaysia
}

\begin{abstract}
As the result of government's initiative and future outlook in uprising the awareness towards the implementation of sustainable elements in construction industries, the Industrialized Building System (IBS) is one of the approaches that had been introduced as an alternative to conventional building method and produce the new strategy of reducing the waste of materials in construction. The IBS approach is actively promoted through several strategies and incentives as an alternative to conventional building methods. Extensive uptakes of modern Information Communication Technology (ICT) applications are able to support the different IBS processes for effective production. However, it is argued that ICT uptake at the organizational level needs to be regularly improved. Thus, this paper fulfills the need to identify the critical barriers to ICT employment and highlighting the ICT drivers in enhancing the IBS management process. Critical barriers and drivers to ICT uptake were identified through questionnaire survey with industry stakeholders and were analyzed using mean index and critical t-value with the use of SPSS software. The critical drivers are top management support and commitment and improving the availability of the technologies. The critical drivers which were identified are significant in ensuring the enhancement of ICT implementation. Hence, any system in place should avoid the highest ranked barriers or seek to alleviate their impact by focusing on the identified drivers in order to enhance implementation of ICT in IBS process management.
\end{abstract}

\section{Introduction}

Information and Communication Technology (ICT) was referred to the combination of manufacturing and services industries that capture, transmit and display data and information electronically [1]. Technological developments have been progressing fast in other industries, but construction for a long period has lagged behind other industries in terms of adoption of new technologies [2]. It is because of many studies having focused on

* Corresponding author: peniel@uthm.edu.my 
the potential for harnessing the new ICT technologies for the good of the construction industry all over the world, due to the industry's awareness of the need [3-7].

In this regard, various studies have gone as far as to regard the gap between the construction industry and ICTs as a major problem affecting its whole performance and tried to diagnose the roots of the difficulties in this regard. Thus, a construction technique in which components are manufactured in a controlled environment (on or off site), transported, positioned and assembled into a structure with minimal additional site works, also known as Industrialized Building System (IBS) [8], are not excluded from the enhancement.

In point of fact, extensive use of modern IT tools is able to support the different IBS processes by enabling more accurate documents and hence good conditions for an effective production where errors are discovered early and problems in the manufacturing and assembly phases can be avoided [9]. Significantly, IBS plays an important role in advancing the sustainability of the constructions especially in reducing the rate for materials to be wasted and maintaining the desirable eco-friendly type of materials. With the effectiveness of ICT implementation, IBS uptake will also increase. However, the current practice of ICT implementation in the tracking of IBS components in Malaysia is rather rare. It appears that most innovative system and components are using innovative materials which are based on imported technologies which are obviously more expensive and difficult to purchase by local contractor [10]. Hence, this paper aims at identifying the critical barriers to ICT employment and highlighting the ICT drivers in enhancing the IBS management process especially in Malaysia construction industry.

\section{Implementation of ICT in IBS}

More sophisticated solutions of ICT based technologies in IBS processes are emerging. Examples include wireless communication, bar-coding and Radio Frequency Identification (RFID) for tagging technologies. A report by Construction Research Institute of Malaysia [11] pointed technology as a main support to impact IBS in the future. 'Building Information Modeling (BIM)' and 'new technology for IBS invented' were classified as the highest ranking scenario of positive impacts on high-high analysis (high impact-high possibilities). In addition, it was stated that further improvement of manufacturing technology is a strong solution to tackle the weakness and threats of IBS adoption.

However, the current practice of ICT uptake in the tracking of IBS components in Malaysia is rather uncommon. There is a lack of effective logistics management in the Malaysian construction industry, where technology intervention plays a very critical role [12]. IBS production process needs a sustained improvement and management in order to ensure proper components are developed and handed over at the right time, in the proper order and without damages.

Among the common ICT applications adopted in the IBS components management process, especially from the management level as indicated by the respondents $(R)$ are the AutoCAD and Microsoft Project software (refer Table 1) [13]. As for the applications employed in the IBS manufacturing yard, there were higher technologies machineries such as the computer controlled batching plants, technology operated moulds, hollow core elematic machine and semi-automated hollow core extruder. Most of the said applications were predominantly used in the design, planning and production stage. However, the usage of the in-house software, Precast Internal System (PIS) was utilised throughout the whole IBS components process management.

The shortcomings of ICT uptake in the construction industry bring forth the need to review possible driver elements for improving ICT uptake in the industry. Several research 
publications [14-18] indicate that people, process and technology are the three key elements that need to be considered for successful uptake of technologies. Together, these three elements create business value [18].

Table 1. Implementation of existing ICT applications [13].

\begin{tabular}{|c|c|c|c|c|c|c|c|}
\hline Ibs process & Existing ict applications & $\begin{array}{c}\mathbf{R} \\
\mathbf{1}\end{array}$ & $\begin{array}{l}\mathbf{R} \\
\mathbf{2}\end{array}$ & $\begin{array}{l}\mathbf{R} \\
\mathbf{3} \\
\end{array}$ & $\begin{array}{l}\mathrm{R} \\
4 \\
\end{array}$ & $\begin{array}{c}\mathbf{R} \\
\mathbf{5}\end{array}$ & $\begin{array}{l}\mathbf{R} \\
6\end{array}$ \\
\hline \multirow{4}{*}{$\begin{array}{l}\text { Project management/ } \\
\text { coordination }\end{array}$} & Precast Internal System (PIS) & & & & & I & \\
\hline & MS Excel & 1 & 1 & 1 & I & 1 & 1 \\
\hline & MS Project & 1 & 1 & 1 & I & 1 & 1 \\
\hline & Primavera & & & & I & & \\
\hline Procurement & ACCPAC & & & & & I & \\
\hline \multirow[t]{5}{*}{ Design } & AutoCAD & I & I & 1 & I & 1 & I \\
\hline & REVIT & & & & & & 1 \\
\hline & TEKLA & & & & I & I & I \\
\hline & STAAD. PRO & & & & & 1 & 1 \\
\hline & RYAN & & & & & & 1 \\
\hline \multirow[t]{5}{*}{$\begin{array}{l}\text { Computer controlled } \\
\text { manufacturing plants }\end{array}$} & $\begin{array}{c}\text { Computer controlled batching } \\
\text { plant }\end{array}$ & l & & I & & & I \\
\hline & Hollow core plants & & & l & & & \\
\hline & Stencilling manufacturing & & & I & & & \\
\hline & Technology operated mould & & & & l & l & l \\
\hline & Elematic machine & & & & & I & \\
\hline
\end{tabular}

However, the study further reiterated that "the people, processes, and technology need a leader", just as "an orchestra needs a conductor". The same analogy can be applied to the adoption and uptake of new and innovative technologies within construction companies. The "conductor" in this case is the policy maker. To successfully implement and use any new technology, it requires policy makers to plan and drive policies and strategies. Policies are "written principles or rules to guide decision-making" [19]. All the four elements are considered important for an organisation to effectively employ ICT. A company cannot employ ICT if it satisfies the requirements of just one element and not the others. Hence, all four elements - policy, process, people and technology - need to work hand-in-hand and symbiotically.

Taking this into account, the main elements for ICT uptake for an organisation to employ ICT should comprise of: (a) Policy makers that believes in the technology and takes strategic measures to drive its adoption, uptake and usage in order to mobilise the industry to implementand benefit from it, (b) Processes that enable and support the successful adoption of the technology, (c) People who have adequate skills, understanding of, and belief in, the technology; and finally (d) Technology applications and infrastructures which are adequate. The four elements to ICT uptake will form the theoretical basis to identify critical barriers and critical drivers to the enhancement of ICT uptake in IBS management process.

\section{Methodology}

This research applied the method of purposive sampling, where the samples are selected based on the knowledge of a population and the purpose of the study [20]. This is a form of non-probability sampling in which it includes specialist knowledge of the research issue. 
Apart from the government IBS policy makers, IBS precast manufacturers were the selected respondents which formed the largest population among the other four IBS systems (e.g. IBS formwork, IBS steel systems) in Malaysia (refer Table 2).

Table 2. IBS Manufacturers in Malaysia [21].

\begin{tabular}{|c|c|}
\hline IBS type & Total manufacturer \\
\hline $\begin{array}{c}\text { Pre-cast concrete framing, panel and box } \\
\text { system }\end{array}$ & 30 \\
\hline Steel framework system & 24 \\
\hline Steel framing system & 25 \\
\hline Prefabricated timber framing system & 4 \\
\hline Block work system & 25 \\
\hline Others (on-site) & 10 \\
\hline Grand total & 118 \\
\hline
\end{tabular}

A total of 41 questionnaires were administered to the entire population of the precast concrete manufacturers and government policy makers, out of which 31 were returned, representing $76 \%$ of the entire questionnaires administered. This is however adjudged high response rate from the construction industry, which in general stands at only $25 \%$ to $35 \%$ [22]. The questionnaire was sent to 33 organizations from the listed companies, of which the majorities are manufacturers under the Registered IBS System Provider (RISP) list in Malaysia. In addition, 8 questionnaires were administered on government policy makers who were direct decision makers in issues pertaining to IBS. The data collection focused on the IBS precast manufacturing process, where ICT applications are more significantly used.

Referring to Fig. 1, the IBS manufacturers and government policy makers were asked to rate the barriers and drivers to ICT uptake in IBS process management from Insignificant to Very Significant range.

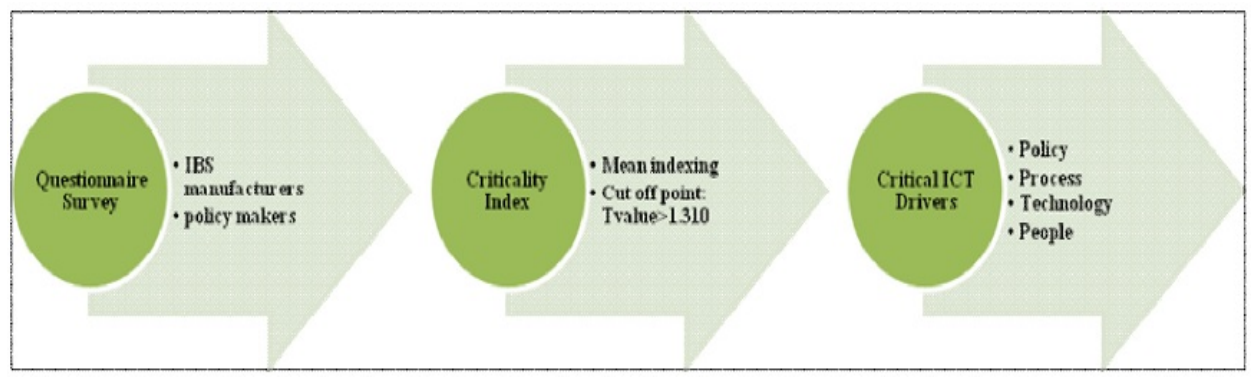

Fig. 1. Flowchart of research methodology.

In order to identify the critical rating from all the sub-components of the ICT barriersdrivers, the mean is fixed at scale ' 3.5 ' since ratings above ' 3 ' represent 'moderate significant', '4' represent 'significant' and '5' represent 'very significant' [23]. The rankings for the ICT uptake barriers and drivers can be obtained by calculating the critical value of the variables. The mean scores ratings of all proposed ICT uptake barriers and drivers were calculated using Equation (1).

$$
\bar{x}=\frac{1(n 1)+2(n 2)+2(n 8)+4(n 4)+5(n 5)}{(n 1+n 2+n 2+n 4+n 5)}
$$


The null hypothesis $(\mathrm{H} 0: \mu 1<\mu 0)$ against the alternative hypothesis $(\mathrm{H} 1: \mu 1>\mu 0)$ were tested, where $\mu 1$ represents the mean of the survey sample population, and $\mu 0$ represents the critical rating above 3.5. The decision rule was to reject $\mathrm{H} 0$ when the result of the observed t-values (to) Equation (2) was larger than the critical t-value (tc) Equation (3) as shown in Equation (4). The criticality of ICT barriers and drivers in this study was examined using Equation (3) and (4).

$$
\begin{aligned}
& \text { to }=\frac{\pi-\mu, 0}{s v / \sqrt{n}} \\
& t c=t(n-1, \alpha) \\
& \text { to }>t c
\end{aligned}
$$

The critical t-value, $\mathrm{t}(30,0.10)=1.310$ with confidence interval $90 \%(\alpha=0.10)$ was set in this study. T-test analysis was employed to rule out the ICT barrier and ICT driver components which carry the mean value lesser than 3.5. ICT uptake barriers and drivers with $\mathrm{t}$-values that are greater than the critical $\mathrm{t}$-value of 1.310 were shortlisted as the critical barrier-driver to ICT uptake. There are similar studies conducted which applied mean indexing and t-tests. Studies have been done by rating the criticality index for the importance of the sustainability-related cost components [24] and using mean indexing to discuss the importance of evaluation elements for customer satisfaction in project management [25]. Apart from that, t-test analysis has been used in past research in identifying the relative important indicators [26, 27]. The critical barriers and drivers to ICT uptake are identified from the four driver elements.

\section{Critical barriers to implement ICT}

From the barrier and driver variables identified from the questionnaire survey, further analyses were conducted to shortlist critical ICT barriers and drivers to IBS process management. This was done with the mean indexing, where those with critical t-value was shortlisted. The complete set of rankings will provide an insight in to the effect of different drivers and barriers to construction ICT while identifying their relative importance in ICT implementation decision making.

The summary of the ICT implementation barriers are shown in Table 3. Out of the 34 ICT implementation barriers, there are only six barriers having t-values above the cut-off point of 1.310. The critical barriers, according to the ascending ranking order are high costs or substantial financial commitment in acquiring the technologies; resistance to change; high cost of specialist software; conventional process; conservative attitude of professionals and high cost for training staff. Six of these critical barriers are under the elements of Cost, People and Process. Technology and Policy are not seen as critical barriers to ICT implementation.

People barrier, being one of the top hindrances to ICT implementation has shown the resistance to change and conservative attitude of the professionals. The construction industry is naturally more cautious towards change and slow to adopt new technology. It is suggested that people tend to resist change due to their habits acquired over time, which is a primary constraint to ICT diffusion [28].

The number one barrier to the implementation of ICT was ICT investment restrictions due to budget constraints [29]. Their research finding is in line with the industry IBS stakeholders' opinion that high cost in acquiring technologies is the main barrier for ICT implementation. Another critical barrier in this research is cost of specialist software too 
high. [30] supported that IT systems are too costly that the organisations are unable to affort IT. High cost investment has been one of the most common barrier in ICT adoption [3135]. Consequently, many construction case studies found that lack of enough training is one of the main barriers to adopting and using IT/ICT applications [33-35]. This research finding highlights the reason behind the lack of enough training. Number six critical ICT implementation barrier is high cost for training staff. Hence, cost is one element that constraints further development of an organisation to greater ICT uptake. However, [36] stated that cost is not a significant determinant of ICT adoption since most SMEs are aware of the government financial support and incentives. Further, [37] too supported this view for the fact that training cost is not an issue since government agencies have offered and provided a number of necessary training programmes. Despite the studies done, the result from this study shows that cost is a critical barrier to ICT implementation in the IBS process management. The underlying rationale could be caused by the fragmented nature in the construction industry and government not meeting the specific needs in the upgrading of ICT knowledge in the industry. Hence, Cost is one very critical barrier that should be seriously looked into as three of all six critical barriers are under the Cost category.

Table 3. Critical ICT Implementation Barriers for All Industry Stakeholders.

\begin{tabular}{|c|l|c|c|}
\hline Rank & \multicolumn{1}{|c|}{ Barriers } & $\begin{array}{c}\text { Barrier } \\
\text { Elements }\end{array}$ & $\begin{array}{c}\text { T-value } \\
\text { (cut-off } \\
\text { point }>\mathbf{1 . 3 1 0})\end{array}$ \\
\hline 1 & $\begin{array}{l}\text { High costs or substantial financial commitment } \\
\text { in acquiring the technologies }\end{array}$ & Costs & 2.855 \\
\hline 2 & Resistance to change & People & 2.299 \\
\hline 3 & Cost of specialist software too high & Costs & 2.219 \\
\hline 4 & Conventional process & Process & 1.58 \\
\hline 5 & Conservative attitude of professionals & People & 1.508 \\
\hline 6 & High cost for training staff & Costs & 1.408 \\
\hline
\end{tabular}

Besides that, People barrier, being one of the top hindrances to ICT implementation has shown the resistance to change and conservative attitude of the professionals. The construction industry is naturally more cautious towards change and slow to adopt new technology. [28] suggested that people tend to resist change due to their habits acquired over time, which is a primary constraint to ICT diffusion. $।$

ICT is hindered from advancing in the IBS process management due to the conventional process that many IBS players still hold on to. ICT will find difficulty to penetrate into processes that are conventional. Hence, it is imperative that the barriers to ICT implementation be overcome with the critical ICT drivers.

\section{Overcoming ICT barriers}

Identifying critical drivers to ICT employment will be a strategy to overcome its barriers. Table 4 stated the top ten critical ICT drivers are shortlisted and summarised according to the ascending ranking order. Ten of these critical ICT implementation drivers are under the elements of People, Technology and Policy, where Process is not seen as a driver to ICT implementation. There are two critical drivers under the People element, namely top management support and commitment and devise better training procedures. [38] refers People to adequate skills, understanding of and belief in the technology. Thus, top down commitment is crucial in every organization, so to ensure all decision making are able to be passed down. Strong commitment from top management, including the senior leadership of 
an organization, is critical to ensuring technological acceptance by creating a supportive context for IT within the organization [39].

Table 4. Top 10 Critical ICT Implementation Drivers for All Industry Stakeholders

\begin{tabular}{|c|l|l|c|}
\hline Rank & $\begin{array}{c}\text { Driver } \\
\text { Elements }\end{array}$ & \multicolumn{1}{c|}{ Drivers } & $\begin{array}{c}\text { T-value } \\
\text { (cut off } \\
\text { point }>\mathbf{1 . 3 1 0})\end{array}$ \\
\hline 1 & People & Top management support and commitment & 8.469 \\
\hline 2 & Technology & Improve availability of the technologies & 8.088 \\
\hline 3 & Policy & $\begin{array}{l}\text { More cooperation between government and IBS players } \\
\text { to promote and implement ICT }\end{array}$ & 7.478 \\
\hline 4 & People & Devise better training procedures & 7.045 \\
\hline 5 & Technology & Provide adequate ICT support (in-house or external) & 6.225 \\
\hline 6 & Policy & Refine IBS Roadmap to encourage greater ICT uptake & 5.903 \\
\hline 7 & Technology & $\begin{array}{l}\text { Allocate adequate resources to implement and upgrade } \\
\text { ICT tools }\end{array}$ & 5.491 \\
\hline 8 & Technology & $\begin{array}{l}\text { Consistent commitment and support to use BIM as a } \\
\text { primary process and technology }\end{array}$ & 5.479 \\
\hline 9 & Policy & More ICT course syllabus to start from tertiary level & 4.507 \\
\hline 10 & Policy & Revision of reward systems & 4.452 \\
\hline
\end{tabular}

Ten of these critical ICT implementation drivers are under the elements of People, Technology and Policy, where Process is not seen as a driver to ICT implementation. There are two critical drivers under the People element, namely top management support and commitment and devise better training procedures. [38] refers People to adequate skills, understanding of and belief in the technology. Thus, top down commitment is crucial in every organization, so to ensure all decision making are able to be passed down. Strong commitment from top management, including the senior leadership of an organization, is critical to ensuring technological acceptance by creating a supportive context for IT within the organization [39].

The second most critical ICT implementation driver element is Technology. In the latest study of [40] technology plays a moderating role on the relationship between government and a construction organisation readiness level in implementing e-procurement. In order to increase the adoption of ICT in IBS process management, there is a need to first improve the availability of technologies. Studies showed that appropriate training increases the likelihood that IT will be accepted, since training tends to bring about better understanding and more favorable attitudes toward the technology and to result in more frequent use of it $[41,42]$. Adequate resources are to be rightfully allocated to implement and upgrade ICT tools whilst consistent commitment to support the use of BIM in the IBS processes. Commitment focuses on end-users who devote themselves to using ICT whereas organisational commitment focuses on top managers who support end-users to use IT/ICT [28]. An organisation's top management also needs to be committed to support and allocate adequate resources for technology investment such as ICT. Commitment is essential to avoid IT project failure [43, 44].

Lastly, Policy is also found to be a critical driver element to greater ICT implementation improvement. [40] suggested that the role of government has a stronger influence on a construction organisation readiness level in implementing ICT. IBS Manufacturers and the Government policy makers agreed that more cooperation is needed between the government and IBS players in order to promote and implement ICT. Other than that, the IBS Roadmap has to be refined and more ICT course syllabus to touch the grass root education. One recurring ICT driver mentioned throughout this study is to revise the reward system [45]. 


\section{Conclusion}

The critical drivers which were identified are significant in ensuring the enhancement of ICT implementation. Ten of these critical ICT implementation drivers are under the categories of People, Technology and Policy, where Process is not seen as a driver category to ICT implementation. The critical drivers, according to the ascending ranking order are top management support and commitment; improve availability of the technologies; more cooperation between government and IBS players to promote and implement ICT; devise better training procedures; provide adequate ICT support (in-house or external); refine IBS Roadmap to encourage greater ICT uptake; allocate adequate resources to implement and upgrade ICT tools; consistent commitment and support to use BIM as a primary process and technology; more ICT course syllabus to start from tertiary level and revision of reward systems. Results of the advancement of IBS in the industries could assist in the provision and improvement of higher sustainability to the construction development. These rankings are important to ensure that the industry tackles the nip of the problem instead of focusing on the less critical barrier issues.

This work was supported by RAGS (R059) Universiti Tun Hussein Onn Malaysia (UTHM).

\section{References}

[1] Organisation for Economic Co-operation and Development, Measuring the Information Economy Report, Infoeconomy, (2002), Retrieved on May 30, 2003 from http://www.oecd/org/sti/measuring

[2] P.S Brandon, T. Kocaturk, and R. Foundation, Virtual Futures for design, construction and procurement, Blackwell Pub, Malden, MA, (2008)

[3] M. Hannus, M. Blasco, M. Bourdeau, M, Böhms, G. Cooper, F. Garas, T. Hassan, A. Kazi, J. Leinonen, and Y. Rezgui, Construction ICT roadmap, Roadcon Project Deliverable Report D, 52, (2003)

[4] A. Adriaanse, H. Voordijk, and G. Dewulf, The use of interorganisational ICT in United States construction projects, Automation in Construction, 19, 73-83, (2010)

[5] S. Kivrak, G. Arslan, and O. Cagatay, Information technology usage impacts on construction projects'success, (2010)

[6] Y. Rezgui, and A. Zarli, The way to the vision of digital construction: A strategic roadmap, Journal of Construction Engineering and Management, 132, 767, (2006)

[7] T. Gajendran, and G. Brewer, Cultural consciousness and the effective implementation of information and communication technology, Construction Innovation: Information, Process, Management, 12, 179-197, (2012)

[8] IBS Roadmap (2003-2010), Construction Industry Development Board (CIDB), Kuala Lumpur, (2003)

[9] J. Lessing, A. Ekholm, and L Stehn, Industrialized Housing - Definition and Loughborough: European Construction Institute, (2005)

[10] IBS Roadmap Review (Final Report) IBS Centre, Construction Industry Development Board, Malaysia, Kuala Lumpur, (2007)

[11] CREAM, The 7th Industrialised Building System (IBS) Roundtable Workshop. Technology Foresight Report, Construction Research Institute of Malaysia, 1-27, (2011)

[12] K.A.M. Kamar, and Z.I. Hamid, Modernising the Malaysian construction industry through the adoption of industrialised building system (IBS), The Sixth Int. Conf. on Multi- National Joint Ventures for Construction Works, Kyoto, Japan, 1-14, (2010) 
[13] P.S.E. Ang, and N. Kasim, ICT-readiness in Industrialised Building System (IBS) management processes: Case studies, 1st FPTP Postgraduate Seminar 2013, Universiti Tun Hussein Onn Malaysia, (2013)

[14] S. Basu, and P. Deshpande, Wipro's People Processes: A Framework for Excellence, White paper. (2004) Retrieved on April 232011 from http://www.wipro.com/insights/wipropeopleprocesses.htm

[15] C. Goolsby, Integrated People + Processes + Tools $=$ Best-of-Breed Service Delivery, Getronics White Paper, (2001) Retrieved on 23 April 2004 http://itpapers.news.com

[16] Fuji Xerox, Aligning People Processes and Technology, (2003) Retrieved on April 23 $2004 \mathrm{http}: / /$ www.fujixerox.com.au

[17] B. Larkin, Aligning People Process and Technology, (2003) Retrieved on April 23 $2004 \mathrm{http}: / / w w w . p a p e r l e s s p a y . o r g / a r t i c l e s / T e c h n o l o g y . p d f$

[18] B. Emmett, IT service management: People process technology, business value, The IT J., Third Quarter, (2002)

[19] Clemson, Definition of Policy, Clemson University - Office of Research Compliance, Definitions of Research Compliance Terms, 2007, Last accessed 14 April 2007, from http: //www.clemson.edu/research/orcSite/orcIRB_DefsP.htm.

[20] A.R. Md Nor, Statistical methods in reserch, Pearson, Malaysia, (2009)

[21] List of Malaysian IBS manufacturers and Registered IBS System Providers (RISP) 2012-2013, Construction Industry Development Board Malaysia (CIDB), Kuala Lumpur, (2013)

[22] R. Fellows, and A. Liu, Research methods for construction, Wiley-Blackwell, West Sussex, (2008)

[23] K.C. Goh, Developing financial decision support for highway infrastructure sustainability, PhD Thesis, Queensland University of Technology, (2011)

[24] K.C. Goh, and J. Yang, Importance of sustainability-related cost components in highway infrastructure: perspective of stakeholders in Australia, J. of Infrastructure Systems, 20(1), (2013)

[25] J.B. Yang, and S.C. Peng, Development of a customer satisfaction evaluation model for construction project management, Building and Environment, 43(4), 458-468, (2008)

[26] J. Wong, and H. Li, Development of a conceptual model for the selection of intelligent building systems, Building and Environment, 41(8), 1106-1123, (2006)

[27] Z. Shehu, and A. Akintoye, Major challenges to the successful implementation and practice of programme management in the construction environment: A critical analysis, Int. J. of Project Management, 28(1), 26-39, (2010)

[28] V. Peansupap, An exploratory approach to the diffusion of ICT in a project environment, $\mathrm{PhD}$ Thesis, RMIT University, Melbourne, Australia, (2004)

[29] S.L. Kajewski, J.R. Crawford, A., Weippert, P.A. Tilley, S.L. McFallan, T.R. Remmers, and M.A. Haug, National Perspective on the Status of ICT in the Australian Construction Industry, (2001)

[30] P. Hawking, A. Stein, D. Wyld, and S. Forster, E-procurement: Is the ugly duckling actually a swan down under?, Asia Pacific J. of Marketing and Logistics, 16(1), 1-26, (2004)

[31] P.E. Love, Z. Irani, H. Li, E.W. Cheng, and Y.C. Raymond, An empirical analysis of the barriers to implementing e-commerce in small-medium sized construction contractors in the state of Victoria, Australia, Construction Innovation: Information, Process, Management, 1(1), 31-41, (2001)

[32] L. Marsh, and R. Flanagan, Measuring the costs and benefits of information technology in construction. Engineering, Construction and Architectural Management, 7(4), 423-35, (2000) 
[33] A. D.Songer, R. Young, and K. Davis, Social architecture for sustainable IT implementation in AEC/EPC, Proc. of IT in Construction in Africa 2001, Mpumalunga, South Africa, (2001)

[34] P. Stephenson, and S. Blaza, Implementing technological change in construction organisations, Proc. of the IT in Construction in Africa, Mpumalunga, South Africa, (2001)

[35] A. Weippert, S.L Kajewski, and P.A. Tilley, Internet-based information and communication systems on remote construction projects: A case study analysis. Construction Innovation, 2(2), 103-16, (2002)

[36] K.S. Tan, S.C Chong, B. Lin, and U.C Eze, Internet-based ICT adoption: Evidence from Malaysian SMEs, Industrial Management and Data Systems, 109(2), 224-244, (2009)

[37] S.S. Alama, and M.K.M. Noor, ICT adoption in small and medium enterprises: An empirical evidence of service sectors in Malaysia, Int. J. Bus. Manag., 4, 112-125, (2009)

[38] K. Ruikar, C.J. Anumba, and P.M. Carrillo, An E-readiness assessment application for construction companies, Automation in Construction, 15(1), 98-110, (2006)

[39] P. Weill, The relationship between investment in information technology and firm performance: A study of the valve manufacturing sector, Information Systems Research, 3(4), 307-333, (1992)

[40] Q. Tran, Huang, D. Liu, and B.H.M. Ekram, A construction enterprise's readiness level in implementing eprocurement: A system engineering assessment model, Systems Engineering Procedia, 131-141, (2011)

[41] L. Raymond, The impact of computer training on the attitudes and usage behavior of small business managers. Laboratoire en économie et gestion des systèmes de petites dimensions, Dép. d'administration et d'économique, Université du Québec à TroisRivières, (1988)

[42] V. Venkatesh, Determinants of perceived ease of use: Integrating control, intrinsic motivation, and emotion into the technology acceptance model, Information Systems Research, 11(4), 342-365, (2000)

[43] D. Leonard-Barton, and J. J Sviokla, Putting expert systems to work, Harvard Business Review, 91-8, (1988)

[44] R.L. Thompson, C.A. Higgins, and J.M. Howell, Personal computing: Toward a conceptual model of utilization, MIS Quarterly, 15(1), 125-43, (1991)

[45] R. Mahbub, An investigation into the barriers to the implementation of automation and robotics technologies in the construction industry, $\mathrm{PhD}$ Thesis, Queensland University of Technology, Australia, (2008) 